\title{
ACRL promotes American libraries at the Frankfurt Book Fair
}

\author{
Highlights from the world's largest book fair
}

by Mazena Pasek and Gordon B. Anderson

A this year's Frankfurt Book Fair, which ran from October 17 through October 23,2000 , three ACRL representatives, funded by a grant from the ACRL Board of Directors, led an exhibit promoting American college and university libraries at the world's largest trade fair devoted to one theme-the book.

How large was the 52nd Frankfurt Book Fair? An article in American Libraries described the 1999 Frankfurt Book Fair: "Try to imagine O'Hare Airport around Christmas, but with the crowds elbowing each other to catch not a flight, but a glimpse of Tom Wolfe. Toni Morrison, or the new Nobel prizewinner, German writer Günter Grass."

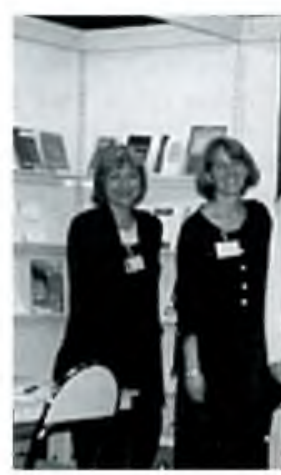

Marcia Pankake (University of Minnesota), Melissa Cast (ACRL), Denise Hibay (New York Public Library), and Marzena Pasek (New York Public Library).

\section{"Everybody comes to Frankfurt because everybody comes to Frankfurt"}

'The book fair's official motto was in evidence everywhere. According to the Fair's Web site at www.frankfurt-bookfair.com, "everybody" totaled some 300,000 visitors (a $7.5 \%$ increase over last year's figure), canvassing an exhibition area of 190,000 square meters.

Some 380,000 books, magazines, maps, multimedia products, and art works from 6,643 individual exhibitors-publishers, multimedia producers and art galleries-from 105 countries were on display. Writers and publishers negotiated the buying and selling of rights of publication, distribution, and translation.

More than 2,100 fair-related events took place in six days; some 1,100 authors were featured in book-signings, readings, lectures, symposia, and receptions. Guest of honor, Poland, was involved in almost 1,000 events.

This year's winner of the fair's prestigious Peace Prize of the German Book-Trade was

\section{About the authors}

Marzena Pasek is European Studies bibliographer at the New York Public Library, e-mail: mpasek@nypl.org, and Gordon B. Anderson is reference librarian and European Studies bibliographer at University of Kansas Libraries, e-mail: ganderson@ukans.edu 


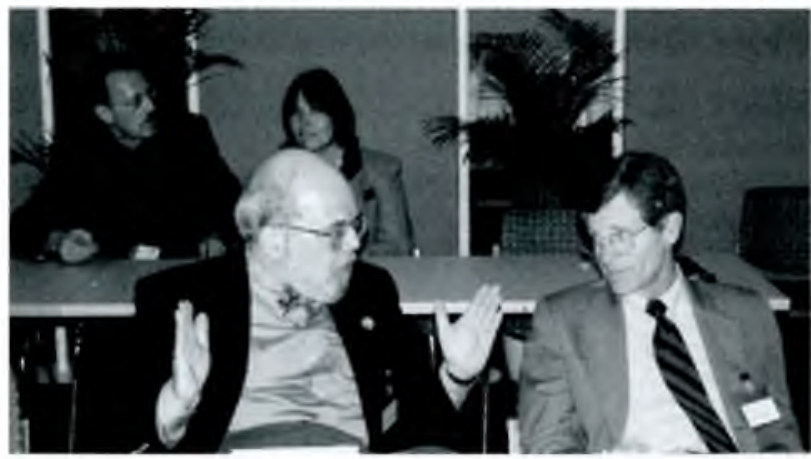

Jim Campbell (University of Virginia) and Ross Atkinson (Cornell University) conversing at the "Knowledge Transfer and Knowledge Management in the 21st Century" symposium.

new U.S. journal Slavic \& East European Information Resources (SEEIR).

Our visitors most often asked about ACRL's position on the impact of electronic technologies on library collections and services, and in response we handed out many copies of "ACRL's Information Literacy Competency Standards for Higher Education" and "Guidelines for Distance Learning Services." With a sturdy laptop and a good Internet connec-

the Algerian writer-in-exile Assia Djebar. The fair's opening ceremonies featured the foreign ministers of Germany, Joschka Fischer; and Poland, Wladyslaw Bartoszewski; the mayor of Frankfurt, Petra Roth; the president of the German Publishers \& Booksellers Association, Roland Ulmer. Two of Poland's several Nobel laureates, the poets Wislawa Szymborska and Czeslaw Milosz, read from their works.

\section{The International Booksellers and Librarians Center}

ACRL's exhibit occupied a strategic spot in the International Booksellers and Librarians Center (IBLC). Started in the early 1980 s by Andreas Werner of the University of Frankfurt, the IBLC has become the place where international booksellers, librarians, and vendors can meet at the Frankfurt Book Fair.

The ACRL exhibit was led by Melissa Cast, ACRL's director of Member Services; Marzena Pasek (New York Public Library), representing the Western European Specialists Section; and Gordon Anderson (University of Kansas), representing the Slavic \& East European Section.

Visitors to the ACRL exhibit included publishers and book distributors, chiefly from Europe; librarians and library-school faculty, also mainly from Europe; and visitors from Asian countries and from the United States.

We offered our guests a wide variety of printed literature for examination: for example, CHOTCE and CGRL News; titles from ACRL's series Publications in Librarianship; WESS's Reference Revieus Europe; and the tion, we showed our visitors a wide variety of electronic resources and reference and information services. Clearly, North American research libraries are the world's model for aggressively exploiting the latest technology and services to provide better access to collections and resources beyond our own libraries.

We are very grateful for the eight other WESSies-Roger Brisson (Penn State University), Jim Campbell (University of Virginia), Jeff Garrett (Northwestern University), Denise Hibay (New York Public Library), AnnMarie Mitchell (University of California, Berkeley), Mike Olson (Harvard University), Marcia Pankake (University of Minnesota), and Brian Skib (University of Michigan)_made our booth their home base. They volunteered many an hour to staffing the exhibit so that we, too, could see something of the fair for ourselves. Our colleagues are excellent ACRL representatives.

\section{"Knowledge Transfer" symposium}

This year Werner and Jeffrey Garrett (this year's chair of WESS), organized a two-day conference at the IBLC entitled "Knowledge Transfer and Knowledge Management in the 21st Century: New Structures and Solutions for Universities and Libraries."

The U.S. speakers included Ross Atkinson, deputy university librarian at Cornell University; James Campbell, director of Library Technology Services at the University of Virginia; Peter Givler, executive director of the Association of American University Presses; Martin Mueller, professor of English and Classics at Northwestern University; and Ann Okerson, 
associate director of the Yale University Library System. Michael Keller, Stanford University librarian and the publisher of High Wire Press, the very successful electronic publishing enterprise of Stanford University Libraries, added important North American expertise to the discussions.

European speakers and participants included library directors from the universities of Bolzano, Essen, Frankfurt, Halle, Mannheim, Milan, Siegen, Stuttgart, and Warsaw, and an official from a German state ministry of education. This first transatlantic librarians' conference at the Frankfurt Book Fair was moderated in English and in German by Professor Peter Lockemann of the University of Karlsruhe. Simultaneous interpreters working U.N.style through headphones made sure that language was never an obstacle, even during the lively discussions following the presentations.

Conference participants in Germany and the United States shared remarkably similar concerns and expectations about the future of e-books and electronic serials, and the degree of saturation that technology has reached very similar levels on both sides of the Atlantic. European participants were impressed, however, with the degree to which their American counterparts use their regional consortia to advantage in dealing with vendors. This subject figures to become the theme for next year's symposium, which the organizers are already at work preparing.

U.S. participants, for their part, were impressed by the Germans' sophisticated research analyzing actual use (and non-use) of electronic journals.

The proceedings of the 1st International Symposium of the IBLC will be published in cooperation with the European University Institute of Florence by Casalini libri. An online version will also be made available via the Frankfurt Book Fair and WESS Web sites.

\section{Notes}

1. Jeffrey Garrett, "U.S. Librarians Show Their Stuff at Frankfurt Book Fair," American Libraries (December 1999): 28-29.

2. A photo album of ACRL's Frankfurt Book Fair exhibit is available at: http:// www.library.northwestern.edu/collections/ garrett/frankfurt/frankfurt00.html.

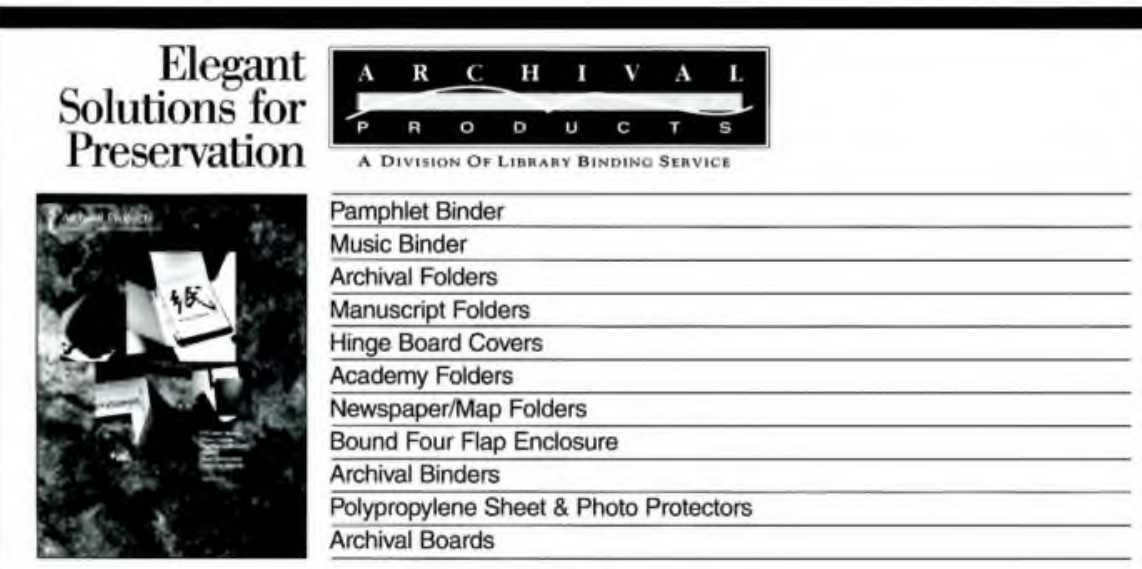

ARCHIVAL PRODUCTS

A Division of Library Binding Service

Call P.O. Box 1413

for a complete

Des Moines, Iowa 50305-1413

catalog

800.526 .5640

Fax 800.262.4091

custserv@archival.com

http://www.archival.com 


\section{licensing}

negotiations

\section{taking control of}

your life?

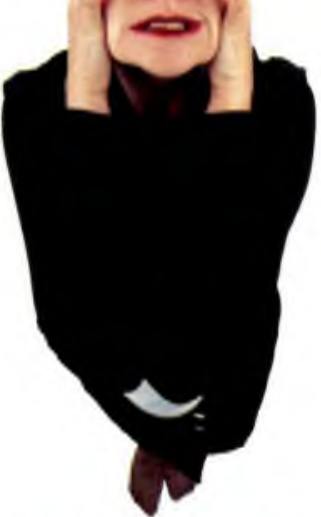

\section{Faxon and RoweCom can help.}

At Faxon, we understand the growing responsibilities facing library professionals today.

That's why we recently introduced our unique Licensing Service, allowing us to negotiate with publishers on your behalf, while ensuring that you have access to your e-journals when you need it.

So while managing print and electronic collections is becoming more complex every day, we are working hard to provide you with innovative, professional services and web-based solutions to make your job easier.

- Comprehensive Subscription Services Providing complete, start-to-finish solutions for identifying, selecting, acquiring. registering and maintaining your print and electronic collections.

\section{- Cutting-edge E-journal Services}

From desktop access and license negotiation to expert electronic resources and support from the industry's only full-time e-journal team, Faxon is the authority in e-journal solutions!

Join the growing number of libraries who are partnering with Faxon to regain control!

\section{www.faxon.com}

- Premier Web-based Services

Discover a host of unique online services designed for the information professional, including:

- Subscription Depot (also offered globally as kLibrary) the industry-leading web interface for online ordering and management

- License Depot ${ }^{\mathrm{sh}}$, containing extensive ejournal information and publisher links

- Information Quest for online delivery of electronic journals

- kStore, the desktop solution for acquiring knowledge resources 